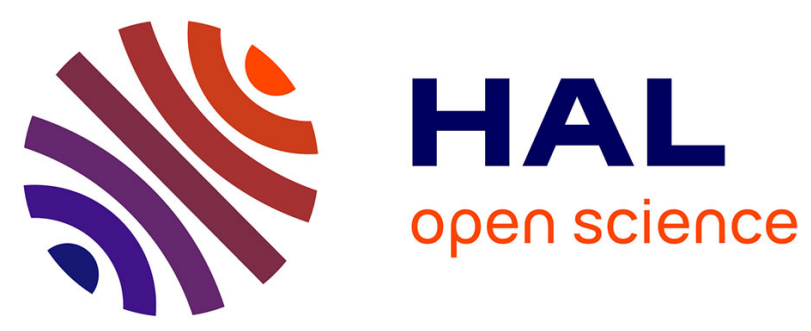

\title{
Potential role of lithospheric mantle composition in the Wilson cycle: a North Atlantic perspective
}

\author{
Pauline Chenin, Suzanne Picazo, Suzon Jammes, G. Manatschal, Othmar \\ Müntener, Garry D. Karner
}

\section{- To cite this version:}

Pauline Chenin, Suzanne Picazo, Suzon Jammes, G. Manatschal, Othmar Müntener, et al.. Potential role of lithospheric mantle composition in the Wilson cycle: a North Atlantic perspective. Journal of the Geological Society of London, 2018, Fifty Years of the Wilson Cycle Concept in Plate Tectonics, Geological Society, London, Special Publications, 470, pp.SP470.10. 10.1144/SP470.10 . hal-01926207

\section{HAL Id: hal-01926207 https://hal.science/hal-01926207}

Submitted on 26 Aug 2019

HAL is a multi-disciplinary open access archive for the deposit and dissemination of scientific research documents, whether they are published or not. The documents may come from teaching and research institutions in France or abroad, or from public or private research centers.
L'archive ouverte pluridisciplinaire HAL, est destinée au dépôt et à la diffusion de documents scientifiques de niveau recherche, publiés ou non, émanant des établissements d'enseignement et de recherche français ou étrangers, des laboratoires publics ou privés. 


\title{
Potential role of lithospheric mantle composition in the Wilson cycle: a North Atlantic perspective
}

\author{
PAULINE CHENIN ${ }^{1 *}$, SUZANNE PICAZO ${ }^{2}$, SUZON JAMMES $^{3}$, \\ GIANRETO MANATSCHAL ${ }^{1}$, OTHMAR MÜNTENER ${ }^{2} \&$ \\ GARRY KARNER ${ }^{4}$ \\ ${ }^{1}$ CNRS-IPGS-EOST, Université de Strasbourg, 1 rue Blessig, \\ 67084 Strasbourg, France \\ ${ }^{2}$ University of Lausanne, Institut des Sciences de la Terre, Bâtiment Géopolis, \\ CH-1015 Lausanne, Switzerland \\ ${ }^{3}$ Texas State University, 601 University Drive, San Marcos, TX 78666, USA \\ ${ }^{4}$ ExxonMobil, URC/Basin and Petroleum Systems Analysis, Hydrocarbon \\ Systems, Houston Campus, Science 1, 22777 Springwoods Village Pkwy, Spring, \\ Houston, TX 77389, USA \\ P.C., 0000-0002-2151-5148 \\ *Correspondence: chenin@unistra.fr
}

\begin{abstract}
Although the Wilson cycle is usually considered in terms of wide oceans floored with normal oceanic crust, numerous orogens result from the closure of embryonic oceans. We discuss how orogenic and postorogenic processes may be controlled by the size/maturity of the inverted basin. We focus on the role of lithospheric mantle in controlling deformation and the magmatic budget. We describe the physical properties (composition, density, rheology) of three types of mantle: inherited, fertilized and depleted oceanic mantle. By comparing these, we highlight that fertilized mantle underlying embryonic oceans is mechanically weaker, less dense and more fertile than other types of mantle. We suggest that orogens resulting from the closure of a narrow, immature extensional system are essentially controlled by mechanical processes without significant thermal and lithological modification. The underlying mantle is fertile and thus has a high potential for magma generation during subsequent tectonic events. Conversely, the thermal state and lithology of orogens resulting from the closure of a wide, mature ocean are largely modified by subduction-related arc magmatism. The underlying mantle wedge is depleted, which may inhibit magma generation during post-orogenic extension. These endmember considerations are supported by observations derived from the Western Europe-North Atlantic region.
\end{abstract}

The paradigm now called the Wilson cycle (Dewey $\&$ Burke 1974) refers to the rift-drift-subductioncollision-collapse evolution occurring repeatedly along particular deformation belts. The model originates from the work of Wilson (1966), who first recognized that the distribution and evolution of the palaeofaunal assemblages of North America and Western Europe required the existence of a major ocean basin separating these continents during the lower and middle Paleozoic, whereas this ocean no longer existed from the late Paleozoic to the middle Mesozoic. Wilson's theory has been widely used to describe the repeated opening and closure of continent collision zones, the conjugate pre-collision margins of which are implicitly considered to be separated by zones of normal oceanic crust.

Embryonic oceans and abandoned hyperextended rift systems are common geological features (e.g. the Porcupine Basin and the Rockall Trough in the North Atlantic) and it is generally recognized that a significant number of orogens involved the closure of such immature rift systems - for example, the Alps (Sengör 1991), the Pyrenees (Boillot \& Capdevila 1977) and most of the Variscides of Western Europe (Franke 2006). However, only a few researchers have attempted to distinguish between orogens resulting from narrow versus wide ocean basins (Sengör 1991; Chenin et al. 2017) and the question of whether minor oceans experience a Wilson cycle comparable with that of wide oceans has not been widely explored.

We focus here on immature extensional systems, which we define as extensional systems whose development stopped before a steady-state seafloor spreading system was initiated. Based on thought experiments and relying on recent data/concepts 


\section{P. CHENIN ET AL.}

and currently developed numerical models, we investigate how the characteristics of orogenic and post-orogenic processes resulting from the closure of such an immature extensional system may differ from those following the closure of a wide oceanic domain (Fig. 1). In particular, we investigate the evolution of the lithospheric mantle during extension and emphasize its impact on the localization of deformation and on the magmatic budget of subsequent tectonic events (i.e. orogenic collapse and/or rifting). We discuss how shortened or incomplete Wilson cycles may differ from the classical Wilson cycle in the light of natural examples from the wellstudied Western Europe-North Atlantic region. This region is of particular interest because it consists of orogens resulting from the closure of both narrow $(<500 \mathrm{~km})$ and/or immature hyperextended rift systems (the Variscides of Western Europe) and wide mature oceans (the Scandinavian Caledonides).

\section{Characteristics of extensional systems}

\section{First-order characteristics}

Extension of the lithosphere, from orogenic collapse to hyperextension and eventual seafloor spreading, is usually achieved through a succession of deformation phases, which form a series of domains with relatively consistent characteristics (Peron-Pinvidic et al. 2013; Sutra et al. 2013; Chenin et al. 2017). Note that we use the term hyperextension to refer to the stage starting when the crust has been stretched to full embrittlement, usually at a crustal stretching factor of c. 3-4 (Perez-Gussinyé \& Reston 2001), and ending either when subcontinental mantle starts to be exhumed or when steady-state seafloor spreading initiates. As extension progresses, the crust and the lithospheric mantle are increasingly modified by strain localization, thermal perturbations, magmatic additions and phase transformations. However, as rifting is generally a localization process progressively focusing deformation until the onset of steadystate seafloor spreading, the specific characteristics formed during the successive stages of extension are preserved from the proximal to the distal part of rifted margins (Fig. 2b; Manatschal et al. 2015).

We consider three major stages of extension, each being associated with the formation of specific physical characteristics (Fig. 2a): (1) the orogenic collapse and early rifting stage, also called the stretching phase; (2) the hyperextension and possible exhumation stage; and (3) the oceanic stage.

Orogenic collapse. The orogenic collapse stage is characterized by gravitational (i.e. topographic) re-equilibration of an over-thickened lithosphere after the termination of orogeny (Dewey 1988; Rey et al. 2001). Orogenic collapse is usually more or less radial, characterized by extension achieved via normal and low-angle detachment faulting in the high-elevation domain (over-thickened crust), compression expressed as thrusting towards the lower elevation surrounding area and strike-slip faulting at all elevations (Dewey 1988; Andersen 1998). These result in an intense structural inheritance. In some cases, orogenic collapse is accompanied and/or followed by intense magmatic activity, as evidenced by widespread mafic to acidic intrusions for instance, in the crust in the Variscan area, in the Basin and Range Province and in the Canadian Cordillera (Costa \& Rey 1995; Vanderhaeghe et al. 1999; Rey et al. 2001; Petri et al. 2016). These former orogenic areas display a flat Moho and a strong seismic layering of the lower crust (Bois et al. 1989; Rey 1993; Vanderhaeghe 2009), interpreted as mafic underplating resulting from the partial melting of the underlying asthenosphere (Goodwin \& McCarthy 1990; Costa \& Rey 1995) or as sheared, formerly ductile or partially molten lower crust (Vanderhaeghe 2009). We use the term magma-poor orogenic collapse to refer to (classical) orogenic collapse that is devoid of extensive magmatic activity (e.g. the Caledonian orogenic collapse; Meissner 1999; Fossen et al. 2014) and magma-rich orogenic collapse for the opposite case.

After orogenic collapse, the thermal heterogeneities are rapidly re-equilibrated (in a few tens of millions of years; see Jaupart \& Mareschal 2007). By contrast, most of the structural and lithological features inherited from orogenic collapse are essentially preserved. During the early stages of a subsequent rifting event (stretching and necking stages), extension does not significantly modify the lithology of the crust or lithospherie mantle (Picazo et al. 2016; Chenin et al. 2017). Thus the lithology of the crust and lithospherie mantle in the proximal and necking domain of continental margins are comparable (Fig. 2b).

Hyperextension/continental mantle exhumation. On further extension, a rift system may reach the stage of hyperextension (Sutra et al. 2013; Doré \& Lundin 2015) and possibly the stage of mantle exhumation. These stages correspond, respectively, to thinning of the fully embrittled crust from $c .10 \mathrm{~km}$ to the exhumation of the subcontinental lithospheric mantle at the seafloor. In these domains, the entire remaining crust and the shallowest part of the subcontinental mantle undergo intense hydrothermal circulation, which forms sericite and illite in crustal rocks (Manatschal 1999, 2004; Pinto et al. 2015) and serpentine, chlorite and talc up to 4-6 km depth in the lithospheric mantle (Hess 1955; Christensen 1970; FrühGreen et al. 2004; Picazo et al. 2012).

In addition to the hydrothermal alteration processes, hyperextension may lead to decompressional 


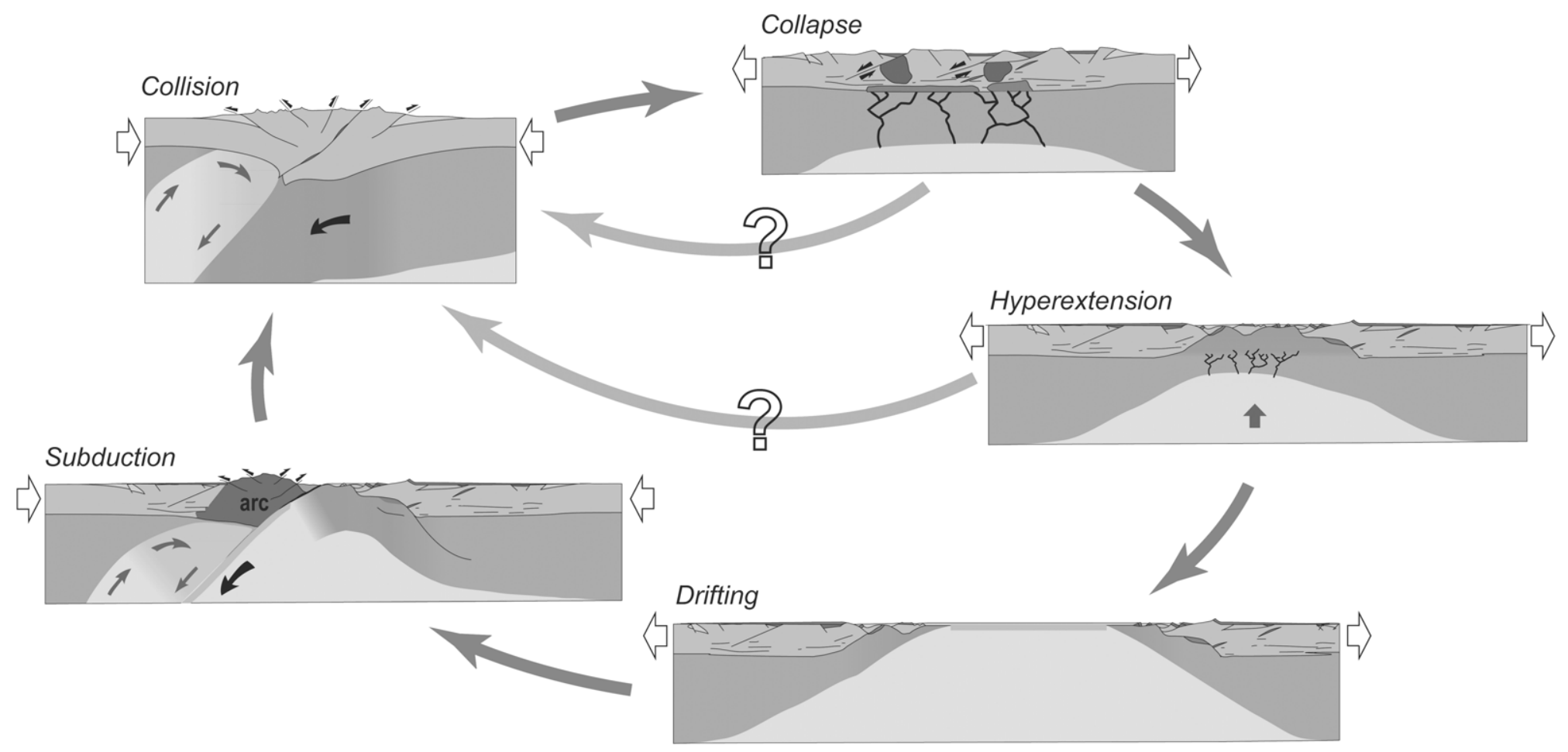

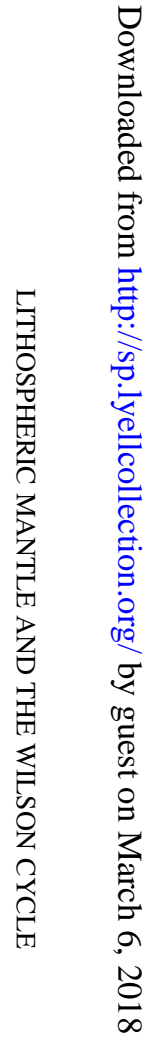

Fig. 1. Classic view of the Wilson cycle and possible short-cuts (light grey arrows). Figure modified after Petri (2014). 


\section{P. CHENIN ET AL.}

(a)
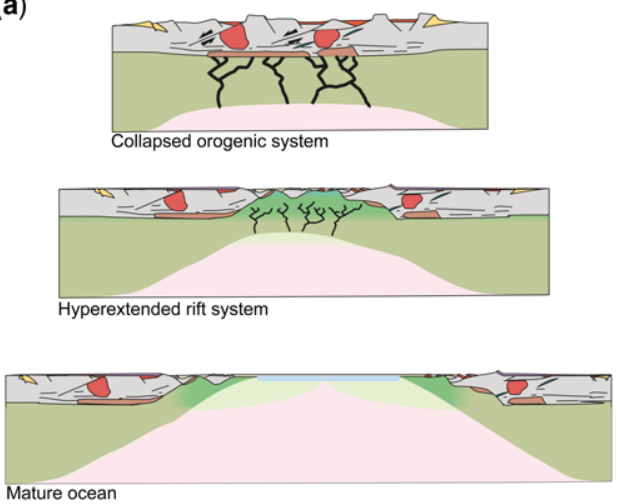

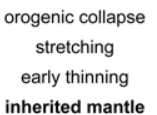

hyperextension

fertile mantle

oceanization depleted mantle

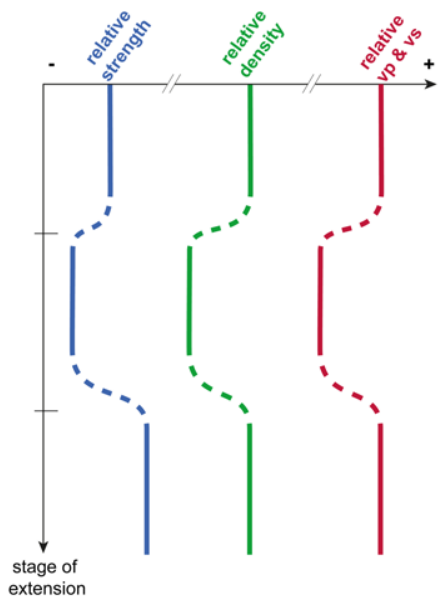

(b)
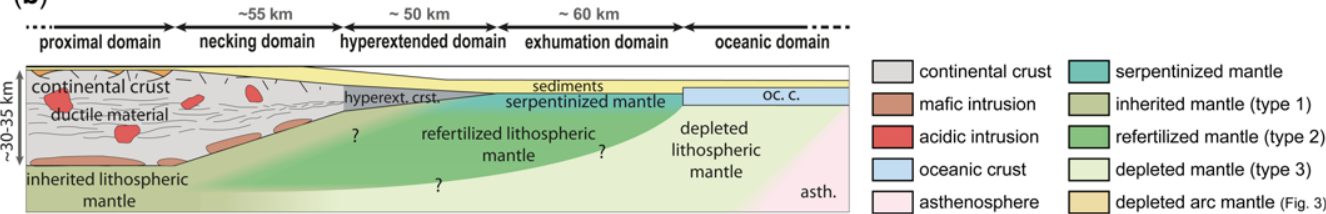

Fig. 2. (a) Main characteristics of extensional systems at various stages of extension and corresponding physical properties of the lithospheric mantle at the centre of the rift (modified after Petri 2014). (b) First-order architecture and lithology of a typical magma-poor rifted margin (modified after Chenin et al. 2017 and Picazo et al. 2016).

melting of the underlying asthenospheric mantle (Latin \& White 1990). At the stage of hyperextension and exhumation, the resulting mid-ocean ridge basalt (MORB)-type melts are not, or are only partially, extracted and tend to stagnate in the overlying lithospheric mantle, fertilizing it (Müntener et al. 2010 and references cited therein). This process tends to progressively homogenize (on a large scale) the continental lithospheric mantle into plagioclasebearing lherzolite in the uppermost $c .30 \mathrm{~km}$ of the mantle (Müntener et al. 2010; Picazo et al. 2016 and references cited therein). Thus orogenic and post-orogenic inheritance in the mantle and remnant continental crust are largely obliterated in the hyperextended and exhumation domains and their lithology is essentially controlled by rift-induced processes (Fig. 2b).

Oceanization. Ultimately, upwelling of the asthenosphere may generate a self-sustaining spreading system for moderate to high seafloor spreading rates (Mutter \& Zehnder 1988; Huismans et al. 2001). In this case, a $c$. 6-7 km thick mafic oceanic crust with a remarkably homogeneous composition (e.g. Gale et al. 2013) is formed (Bown \& White 1994; Dick et al. 2003). At the same time, the underlying asthenospheric source mantle is generally thought to evolve from a lherzolite depleted only in highly incompatible elements to a harzburgite composition depleted in both major and trace elements (see Saunders et al. 1988, their fig. 7). Figure 2b illustrates the first-order architecture, lithology and mantle types at the rifted margins of a typical ocean.

\section{Evolution of the lithospheric mantle}

Experimental studies, thermomechanical numerical modelling and flexure observations generally support the view that most of the strength of the lithosphere resides in the mantle (e.g. Chen \& Molnar 1983; Burov \& Watts 2006), although Maggi et al. (2000) and Jackson (2002) questioned the dominant strength of the upper mantle based on the focal depth of intraplate earthquakes. Thus during lithosphericscale deformation, the lithospheric mantle appears to have a dominant role in controlling the localization of deformation (e.g. Gueydan et al. 2008; Rosenbaum et al. 2008). Anderson (2006) and Meyer et al. (2007) suggested that compositional heterogeneities within the mantle may control the nature and volume of magmatic activity. However, the mantle is still very poorly known and its impact on the characteristics of tectonic systems has been largely ignored. In the following analysis, we attempt to integrate the most recent knowledge - from small-scale petrological studies to large-scale geophysical studies - into a 


\section{LITHOSPHERIC MANTLE AND THE WILSON CYCLE}

coherent, first-order model of the evolution of the lithospheric mantle in extensional systems. Based on the petrological data from Western Europe reviewed by Picazo et al. (2016) and using the algorithms of Hacker et al. (2003), we provide estimates of the density and seismic velocities for the three types of mantle - namely, inherited (subcontinental), fertilized (hyperextended rift systems) and oceanic (steady-state seafloor spreading) mantle.

Highly heterogeneous inherited mantle (mantle type 1 ). There is growing evidence that the upper mantle is highly heterogeneous 'in all parameters and at all scales' (Anderson 2006), essentially as a consequence of tectonic and magmatic processes. These processes include, for example, subduction and the partial melting of hydrated and altered oceanic crust and the overlying sediments, the delamination and partial melting of thickened continental crust, and decompression and/or flux melting at subduction zones, all of which cause large-scale heterogeneities (Jagoutz et al. 2011). Partial melting of the upper mantle may also occur during both orogenic and post-orogenic evolution, such as in the Variscides (Timmerman 2004), contributing to regional compositional heterogeneities that are internally relatively homogeneous (Picazo et al. 2016). Interaction with possible rising plumes from the lower mantle may also modify the composition of the upper mantle (Baker et al. 1998). Therefore the lithospheric mantle in a former orogenic domain can be expected to be highly heterogeneous, which is supported by observations from the Variscan orogenic domain of Western Europe (Picazo et al. 2016) as well as regional density and P-wave velocity anomalies (Artemieva et al. 2006).

Table 1 provides end-member modal compositions for the inherited type of mantle (mantle type 1) based on the modal composition of peridotites in the Western and Central Alps (Müntener et al. 2010) and assuming that the compositional variability of the subcontinental mantle is comparable across Western and Central Europe (Picazo et al. 2016). We distinguish between a fertile end-member (mantle type la; Table 1) and a depleted end-member (mantle type $1 \mathrm{~b}$; Table 1) that underwent an intense episode of partial melting - namely, the thermal event that followed the collapse of Variscan topography. Note that this type of mantle is rarely exhumed (McCarthy \& Müntener 2015). The density of the fertile and depleted end-members are comparable at pressures $<2.5 \mathrm{GPa}(80 \mathrm{~km})$, but at $2.5 \mathrm{GPa}$ the depleted end-member (mantle type $\mathrm{lb}$ ) is denser by $2 \%$ than the fertile end-member (mantle type la; Table 2 and Fig. 3b). P- and S-wave seismic velocities are faster by $c .1 .2$ and $1.5 \%$, respectively, in mantle type $\mathrm{lb}$ than in mantle type la at pressures

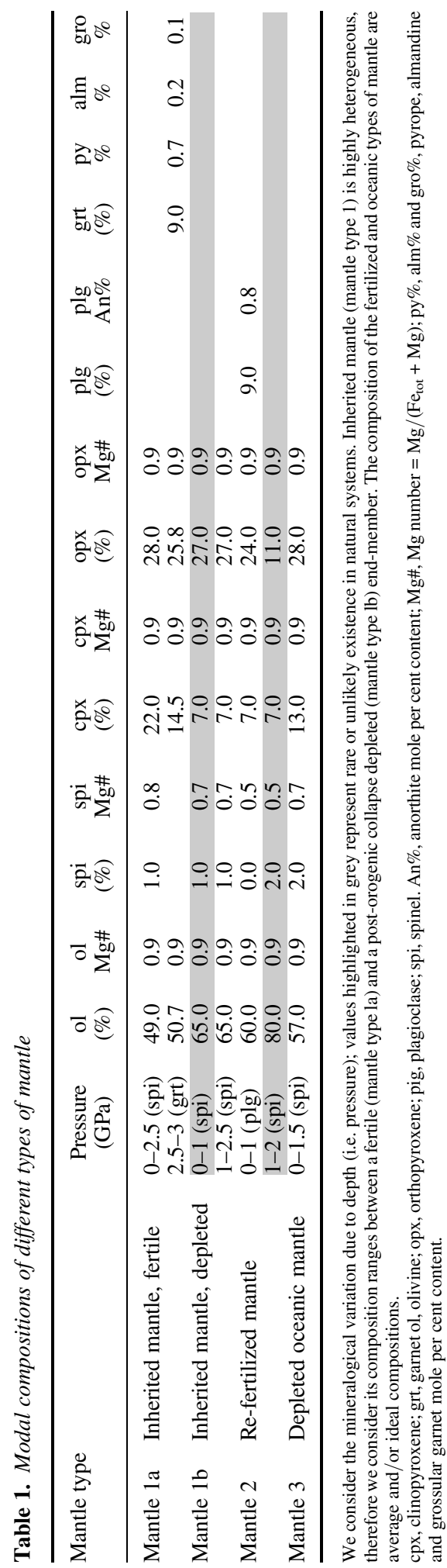




\section{P. CHENIN ET AL.}

Table 2. Density corresponding to the different mantle types calculated with the modal and mineral compositions described in Table 1 using the algorithm from Hacker et al. (2003)

\begin{tabular}{|c|c|c|c|c|c|c|c|c|}
\hline \multirow[b]{2}{*}{ Mantle type } & \multirow[b]{2}{*}{ Pressure (GPa) } & \multicolumn{7}{|c|}{ Temperature $\left({ }^{\circ} \mathrm{C}\right)$} \\
\hline & & 700 & 800 & 900 & 1000 & 1100 & 1200 & 1300 \\
\hline \multirow[t]{6}{*}{ Mantle 1a } & 0.5 & 3.26 & 3.25 & 3.24 & 3.22 & 3.21 & 3.20 & 3.18 \\
\hline & 1 & 3.28 & 3.26 & 3.25 & 3.24 & 3.23 & 3.21 & 3.20 \\
\hline & 1.5 & 3.29 & 3.28 & 3.27 & 3.25 & 3.24 & 3.23 & 3.22 \\
\hline & 2 & 3.30 & 3.29 & 3.28 & 3.27 & 3.26 & 3.25 & 3.23 \\
\hline & 2.5 & 3.38 & 3.37 & 3.36 & 3.35 & 3.34 & 3.33 & 3.32 \\
\hline & 3 & 3.40 & 3.39 & 3.38 & 3.37 & 3.35 & 3.34 & 3.33 \\
\hline \multirow[t]{5}{*}{ Mantle 1b } & 0.5 & 3.26 & 3.25 & 3.24 & 3.23 & 3.21 & 3.20 & 3.19 \\
\hline & 1 & 3.28 & 3.27 & 3.25 & 3.24 & 3.23 & 3.22 & 3.20 \\
\hline & 1.5 & 3.29 & 3.28 & 3.27 & 3.26 & 3.24 & 3.23 & 3.22 \\
\hline & 2 & 3.31 & 3.30 & 3.28 & 3.27 & 3.26 & 3.25 & 3.24 \\
\hline & 2.5 & 3.32 & 3.31 & 3.30 & 3.29 & 3.28 & 3.26 & 3.25 \\
\hline \multirow[t]{4}{*}{ Mantle 2} & 0.5 & 3.21 & 3.20 & 3.19 & 3.18 & 3.17 & 3.15 & 3.14 \\
\hline & 1 & 3.23 & 3.22 & 3.21 & 3.19 & 3.18 & 3.17 & 3.16 \\
\hline & 1.5 & 3.31 & 3.30 & 3.29 & 3.27 & 3.26 & 3.25 & 3.23 \\
\hline & 2 & 3.32 & 3.31 & 3.30 & 3.29 & 3.27 & 3.26 & 3.25 \\
\hline \multirow[t]{3}{*}{ Mantle 3} & 0.5 & 3.27 & 3.26 & 3.25 & 3.24 & 3.22 & 3.21 & 3.20 \\
\hline & 1 & 3.29 & 3.28 & 3.26 & 3.25 & 3.24 & 3.23 & 3.21 \\
\hline & 1.5 & 3.30 & 3.29 & 3.28 & 3.27 & 3.26 & 3.24 & 3.23 \\
\hline
\end{tabular}

Values highlighted in grey represent rare or unlikely existence in natural systems.

$<2.5 \mathrm{GPa}$ and comparable for pressures $>2.5 \mathrm{GPa}$ (Table 3, right-hand side of Fig. 2a and Fig. 3c, d).

To estimate the relative strength of the different types of mantle (Fig. 3), we built a depth-dependent stress profile based on average mineralogical compositions (Table 1) using the polymineralic parametrization developed by Jammes et al. (2015) and Jammes \& Lavier (2016). The polymineralic rheology is created by randomly distributing the mineral phases and their rheological properties among the elements of numerical grids. For each phase, the parameters of the viscous flow law are obtained from laboratory measurements. We use dry olivine (Goetze \& Poirier 1978), clinopyroxene (HierMajumder et al. 2005), orthopyroxene (Raleigh et al. 1971) and plagioclase (Shelton \& Tullis 1981) in different proportions depending on the mantle type (see Table 1 for percentages). For each mineral phase, the transition from brittle to ductile behaviour depends on the plastic strain, temperature and pressure in the corresponding element. Therefore, under certain conditions of pressure and temperature, the polymineralic material generated is semi-brittle because one or two phases deform in a brittle manner while the other phase exhibits a ductile behaviour, or semi-ductile when all phases deform in a ductile manner, but present an important difference in strength (Jammes et al. 2015; Jammes \& Lavier 2016). Because the distribution of the mineral phases in this type of model is random, we built the depth-dependent stress profile for one $x$-coordinate using the geothermal gradient shown in Figure $3 \mathrm{a}$ and a strain rate equal to $10^{-15} \mathrm{~s}^{-1}$. The comparison between the depth-dependent stress profile obtained for the polymineralic material (black curve in Fig. 3) and each mineral phase (olivine, clinopyroxene, orthopyroxene and plagioclase; see corresponding coloured curves in Fig. 3e-h) allows us to identify the different rheological behaviours (brittle, semi-brittle, semi-ductile, ductile) as a function of the depth in the mantle.

Figure $3 e$, f show the depth-dependent stress profile of the fertile inherited mantle end-member (mantle type la) and the depleted inherited mantle end-member (mantle type lb). The depth-dependent stress profile of olivine, clinopyroxene and orthopyroxene are also plotted for comparison. For mantle types la and $\mathrm{lb}$, we observe that below $25 \mathrm{~km}$ depth the mantle is characterized by a brittle behaviour. Between 25 and $40 \mathrm{~km}$, only olivine is in the brittle regime, so that the mantle is characterized by a semibrittle behaviour. Numerical models predict that, in this case, deformation is accommodated by localized anastomosing shear zones (Jammes et al. 2015; Jammes \& Lavier 2016). Between 40 and $60 \mathrm{~km}$ depth, the three mineral phases are in the ductile regime, but there is still an important strength contrast between olivine and pyroxene. The rheological behaviour is then described as semi-ductile and numerical models predict the formation of localized anastomosing shear zones (Jammes et al. 2015; Jammes \& Lavier 2016). Beyond $60 \mathrm{~km}$ depth, the 


\section{LITHOSPHERIC MANTLE AND THE WILSON CYCLE}

(a) Geotherm

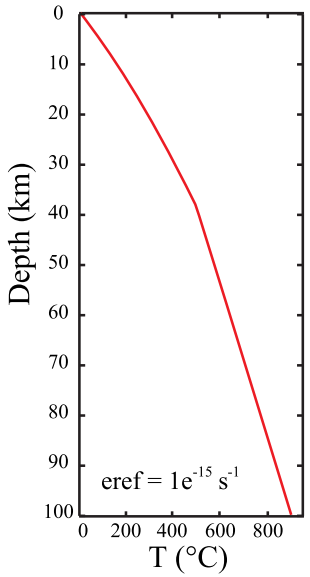

(e) Mantle type 1a

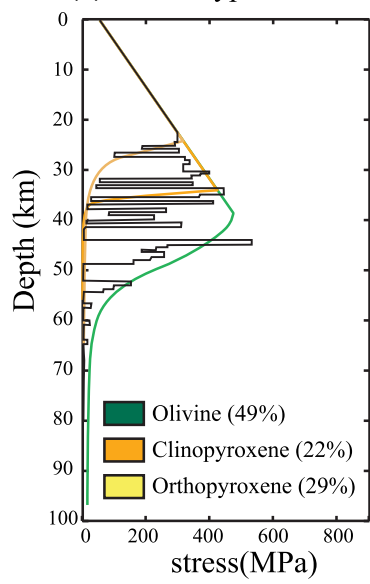

(b) Density

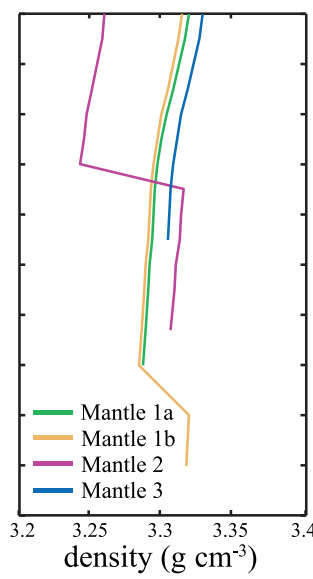

(f) Mantle type $1 \mathrm{~b}$

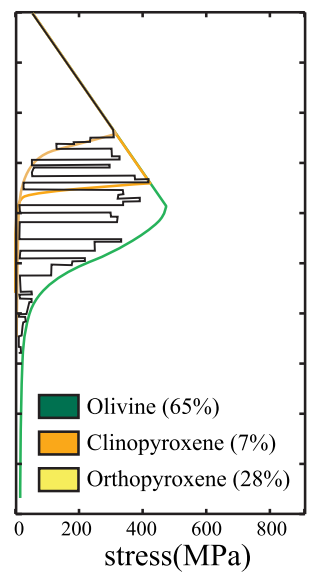

(c) $\mathrm{V}_{\mathrm{P}}$

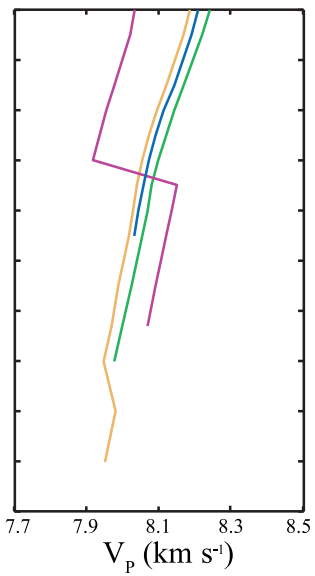

(g) Mantle type 2

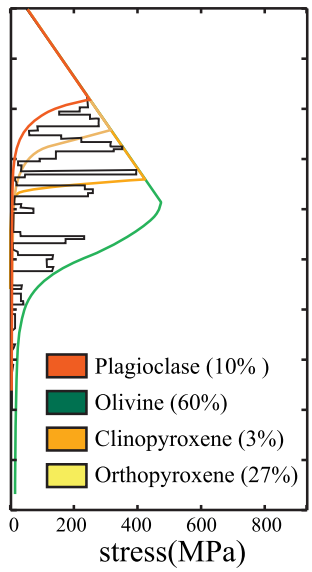

(d) $\mathrm{V}_{\mathrm{S}}$

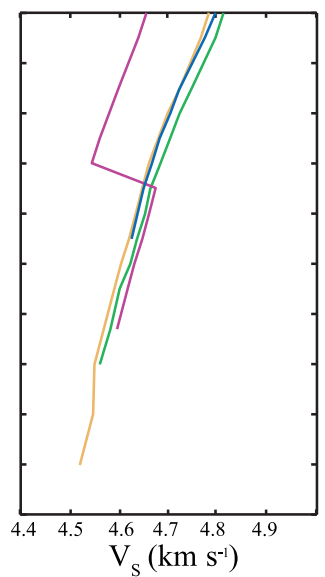

(h) Mantle type 3

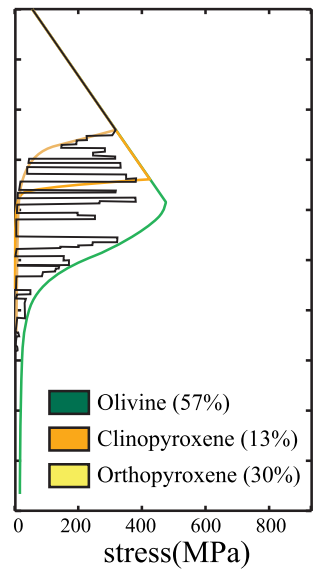

Fig. 3. (a) Geothermal gradient and strain rate (eref) used for calculation of the different profiles shown in this Figure, (b) Density, (c) P-wave and (d) S-wave seismic velocities of the four types of mantle along the geotherm shown in panel $(\mathrm{a}) ;(\mathrm{e}-\mathrm{h})$ : Depth-dependent stress profile of the different types of mantle designed using the parametrization of Jammes et al. (2015). We consider only the main minerals (proportion $>5 \%$ ), namely olivine, pyroxene and plagioclase feldspar, (e) Mantle type la: Inherited mantle - fertile end-member (f) Mantle type lb: Inherited mantle - depleted end-member; (g) Mantle type 2: Fertilized mantle; (h) Mantle type 3: Depleted oceanic mantle.

deformation is fully ductile and numerical models predict the formation of distributed shear zones (Jammes et al. 2015; Jammes \& Lavier 2016).

The main difference between the fertile inherited (la) and depleted inherited (lb) mantle is the relative proportion of olivine and clinopyroxene. The work by Jammes et al. (2015) suggests that this variation affects the localization of the deformation. A decrease in the percentage of weak phases (orthopyroxene and clinopyroxene) in favour of strong phases (olivine) localizes strain, which may lead to the formation of localized shear zones. As a consequence, we expect that deformation will localize earlier in an inherited depleted mantle than in an inherited fertile mantle.

Fertilized mantle (mantle type 2). Growing evidence supports that, during hyperextension, the infiltration and stagnation of melt resulting from asthenospheric decompression melting fertilizes the overlying subcontinental lithospheric mantle (e.g. Müntener et al. 2004). Observations by Picazo et al. (2016) support the view that fertilized mantle evolves progressively from a highly heterogeneous composition 
Table 3. Seismic velocities corresponding to the composition of the different mantle types defined in Table 1 calculated using the algorithm by Hacker et al. (2003)

\begin{tabular}{|c|c|c|c|c|c|c|c|c|c|c|c|c|c|c|c|}
\hline \multirow{3}{*}{$\begin{array}{l}\text { Mantle } \\
\text { type }\end{array}$} & \multirow[b]{3}{*}{ Pressure (GPa) } & \multicolumn{14}{|c|}{ Temperature $\left({ }^{\circ} \mathrm{C}\right)$} \\
\hline & & \multicolumn{2}{|c|}{700} & \multicolumn{2}{|c|}{800} & \multicolumn{2}{|c|}{900} & \multicolumn{2}{|c|}{1000} & \multicolumn{2}{|c|}{1100} & \multicolumn{2}{|c|}{1200} & \multicolumn{2}{|c|}{1300} \\
\hline & & $v_{\mathrm{p}}$ & $v_{\mathrm{s}}$ & $v_{\mathrm{p}}$ & $v_{\mathrm{s}}$ & $v_{\mathrm{p}}$ & $v_{\mathrm{s}}$ & $v_{\mathrm{p}}$ & $v_{\mathrm{s}}$ & $v_{\mathrm{p}}$ & $v_{\mathrm{s}}$ & $v_{\mathrm{p}}$ & $v_{\mathrm{s}}$ & $v_{\mathrm{p}}$ & $v_{\mathrm{s}}$ \\
\hline \multirow[t]{6}{*}{ Mantle 1a } & 0.5 & 7.76 & 4.47 & 7.70 & 4.42 & 7.63 & 4.38 & 7.55 & 4.33 & 7.48 & 4.28 & 7.41 & 4.24 & 7.34 & 4.19 \\
\hline & 1 & 7.83 & 4.49 & 7.76 & 4.44 & 7.69 & 4.40 & 7.62 & 4.35 & 7.55 & 4.31 & 7.48 & 4.26 & 7.41 & 4.21 \\
\hline & 1.5 & 7.89 & 4.51 & 7.82 & 4.46 & 7.75 & 4.42 & 7.68 & 4.37 & 7.61 & 4.33 & 7.54 & 4.28 & 7.47 & 4.23 \\
\hline & 2 & 7.95 & 4.53 & 7.88 & 4.48 & 7.81 & 4.44 & 7.75 & 4.39 & 7.68 & 4.35 & 7.61 & 4.30 & 7.54 & 4.25 \\
\hline & 2.5 & 8.07 & 4.58 & 8.00 & 4.53 & 7.94 & 4.49 & 7.87 & 4.45 & 7.81 & 4.40 & 7.74 & 4.36 & 7.67 & 4.31 \\
\hline & 3 & 8.12 & 4.59 & 8.06 & 4.55 & 7.99 & 4.51 & 7.93 & 4.46 & 7.86 & 4.42 & 7.80 & 4.38 & 7.73 & 4.33 \\
\hline \multirow{5}{*}{ Mantle $1 \mathrm{~b}$} & 0.5 & 7.86 & 4.54 & 7.79 & 4.49 & 7.72 & 4.45 & 7.65 & 4.40 & 7.58 & 4.35 & 7.51 & 4.31 & 7.44 & 4.26 \\
\hline & 1 & 7.92 & 4.55 & 7.86 & 4.51 & 7.79 & 4.46 & 7.72 & 4.42 & 7.65 & 4.37 & 7.58 & 4.33 & 7.51 & 4.28 \\
\hline & 1.5 & 7.98 & 4.57 & 7.92 & 4.53 & 7.85 & 4.48 & 7.78 & 4.44 & 7.71 & 4.39 & 7.64 & 4.35 & 7.57 & 4.30 \\
\hline & 2 & 8.04 & 4.59 & 7.98 & 4.55 & 7.91 & 4.50 & 7.84 & 4.46 & 7.77 & 4.41 & 7.70 & 4.37 & 7.63 & 4.32 \\
\hline & 2.5 & 8.10 & 4.61 & 8.03 & 4.56 & 7.97 & 4.52 & 7.90 & 4.47 & 7.83 & 4.43 & 7.76 & 4.38 & 7.69 & 4.34 \\
\hline \multirow[t]{4}{*}{ Mantle 2} & 0.5 & 7.71 & 4.41 & 7.65 & 4.37 & 7.58 & 4.33 & 7.52 & 4.29 & 7.45 & 4.25 & 7.39 & 4.20 & 7.32 & 4.16 \\
\hline & 1 & 7.78 & 4.44 & 7.71 & 4.40 & 7.65 & 4.35 & 7.59 & 4.31 & 7.52 & 4.27 & 7.46 & 4.23 & 7.39 & 4.19 \\
\hline & 1.5 & 8.08 & 4.60 & 8.02 & 4.56 & 7.95 & 4.52 & 7.89 & 4.47 & 7.83 & 4.43 & 7.76 & 4.39 & 7.70 & 4.35 \\
\hline & 2 & 8.13 & 4.62 & 8.07 & 4.57 & 8.01 & 4.53 & 7.95 & 4.49 & 7.88 & 4.45 & 7.82 & 4.41 & 7.76 & 4.37 \\
\hline \multirow[t]{3}{*}{ Mantle 3} & 0.5 & 7.81 & 4.50 & 7.74 & 4.45 & 7.67 & 4.41 & 7.60 & 4.36 & 7.53 & 4.32 & 7.46 & 4.27 & 7.39 & 4.22 \\
\hline & 1 & 7.88 & 4.52 & 7.81 & 4.47 & 7.74 & 4.43 & 7.67 & 4.38 & 7.60 & 4.34 & 7.53 & 4.29 & 7.46 & 4.25 \\
\hline & 1.5 & 7.94 & 4.54 & 7.87 & 4.49 & 7.80 & 4.45 & 7.73 & 4.40 & 7.66 & 4.36 & 7.59 & 4.31 & 7.52 & 4.27 \\
\hline
\end{tabular}

Values highlighted in grey represent rare or unlikely existence in natural systems. 


\section{LITHOSPHERIC MANTLE AND THE WILSON CYCLE}

with essentially inherited mantle (mantle type 1) characteristics in the proximal part of the hyperextended domain towards an ideally homogeneous plagioclase-bearing peridotite in more distal parts of the domain (mantle type 2; see Table 1).

To calculate the density of fertilized mantle (mantle type 2), we use the modal composition of Western and Central Alps ophiolites from Müntener et al. (2010) and assume that the composition of fertilized mantle is comparable (Picazo et al. 2016). Fertilized mantle is characterized by a density reduced by c. $1.4 \%$ relative to mantle type 1 for pressures $<1 \mathrm{GPa}$ (c. $35 \mathrm{~km}$ ) (Table 2, Fig. 3b; see also Simon $\&$ Podladchikov 2008). Fertilized mantle becomes denser at greater depths due to higher amounts of modal garnet. However, because the amount of fertilized mantle is extremely limited compared with that of inherited mantle, this effect can be neglected.

Fertilized mantle is also characterized by seismic velocities that are reduced by $c .1 \%$ for pressures up to $1 \mathrm{GPa}$ and by $>2 \%$ at greater pressures (Table 3, Fig. 3c, d). This difference may partly explain the anomalous (i.e. not only due to temperature) decrease in seismic velocity commonly observed in the mantle underlying immature basins (incipient or abandoned rift systems) or at hyperextended rifted margins - for example, beneath the southern part of the Porcupine Basin (O'Reilly et al. 2006) and beneath the hyperextended part of the Iberian margin (Afilhado et al. 2008), Newfoundland margin (Lau et al. 2006) and Flemish Cap (Funck 2003). Although serpentinization is presumably the main cause of the decrease in velocity up to $6 \mathrm{~km}$ beneath the seafloor, it cannot account for the decrease at greater depths because serpentine becomes unstable. The existence of fertile mantle may account for reduced velocity up to $10 \mathrm{~km}$ beneath the seafloor.

The existence of plagioclase in the fertilized mantle (mantle type 2) strongly affects the depthdependent stress profile. Figure $3 \mathrm{~g}$ shows that plagioclase is weaker than both pyroxene and olivine. As a result, the fertilized mantle has a semi-brittle behaviour between 18 and $40 \mathrm{~km}$. The domain where deformation can be accommodated along localized anastomosing shear zones is consequently wider than in the inherited mantle, which favours decoupling of the deformation. Because the rheology and thickness of the decoupling layer strongly control contractional deformation processes (Beaumont et al. 1994; Pfiffner et al. 2000; Jammes \& Huismans 2012), the weaker rheology of fertilized mantle may have major consequences for the localization of deformation at the onset of basin reversal.

Homogeneous mid-ocean ridge mantle (mantle type 3). During steady-state seafloor spreading, the asthenospheric mantle is undergoing decompression melting and produces a remarkably homogeneous oceanic crust (MORB). Even if it was initially heterogeneous, the remaining mantle source becomes uniformly depleted because of the relatively high degree of partial melting (Anderson 2006). In contrast to fertilization, depletion related to seafloor spreading has a limited effect on density $(<0.5 \%$ variation; Table 2, Fig. 3b) and on seismic velocity (mantle type 3 faster by c. $0.6 \%$ than mantle type 1 ; Table 3, Fig. 3c, d; Schutt \& Lesher 2006). Note that density and velocity variations related to thermal anomalies and to the presence of melt are thought to be much more important than those related to composition in the upper mantle (Sobolev et al. 1996; Goes et al. 2000; Cammarano et al. 2003).

\section{Reversal and collision of extensional systems}

Any extensional system may be reversed when the background stress changes to relative compression. We describe how the characteristics of the resulting orogen and possible subsequent extensional events (orogenic collapse and/or rifting) may be influenced by the size/maturity of the extensional system involved.

\section{Collapsed orogenic systems}

During the reversal of a collapsed system or of a rift basin that never reached the stage of hyperextension, shortening is presumably not sufficient to cause significant thermal or compositional modification of the crust or mantle. The reversal of systems with small extensions (rifts) is dominantly a mechanical process, governed by structural, lithological and thermal inheritance (Sengör 1991; Chenin et al. 2017).

In the case of a magma-poor orogenic collapse, structural inheritance dominates largely over thermal and lithological inheritance. Structural inheritance provides immediate and long-term weaknesses, which are usually reactivated during subsequent tectonic events when appropriately oriented with respect to the stress direction (Ring 1994; Withjack et al. 2010).

However, in the case of a magma-rich collapse, the thermal and lithological inheritance may dominate over structural heterogeneities. In the early stages of orogeny or orogenic collapse, the orogenic domain is characterized by a high heat flow due to high radiogenic production in the over-thickened crust and/or from percolating melts caused by the partial melting of the lower crust and/or the asthenosphere. This hot thermal state results in weakening of the orogenic region, favouring the localization of deformation during subsequent tectonic events (see Huismans \& Beaumont 2011; Brune et al. 2014; Petersen \& Schiffer 2016). 


\section{P. CHENIN ET AL}

When most of the topography has been eroded and the lithosphere has thermally recovered, a significant proportion of the crust may consist of mafic intrusions and granulite facies rocks, which result from the magmatic event or from deep burial. After the termination of magmatic activity and associated heat advection, these rocks contribute to lower geothermal gradients because their radiogenic production is lower than that of average continental crust (for a review, see Krabbendam 2001). Mafic intrusions have a stronger rheology than the encompassing quartzo-feldspatic crust (e.g. Kohlstedt et al. 1995). As a result, the former orogenic region becomes relatively strong and is less deformed during subsequent tectonic events (Yamasaki \& Gernigon 2009; Chenin et al. 2015).

\section{Hyperextended rift systems to embryonic oceans}

Examples of orogens resulting from the closure of a hyperextended rift system or immature ocean include the Pyrenees (Lagabrielle \& Bodinier 2008; Tugend et al. 2015) and the Alps (Mohn et al. 2014). In both cases, orogeny was essentially a mechanical process largely devoid of subductionrelated magmatic activity, thus the architecture of the initial margins is relatively well preserved (Beltrando et al. 2014; Mohn et al. 2014; Tugend et al. 2015).

In the Pyrenees, the Alps and the southern Iberian abyssal plain, compressional deformation initiated at the limit between either the hyperextended and the exhumation domains, or within the exhumation domain (Peron-Pinvidic et al. 2008; Tugend et al. 2014). Peron-Pinvidic et al. (2008) and Lundin \& Doré (2011) proposed that serpentine may act as a stress guide during subduction initiation because it is weaker than peridotite, continental crust and oceanic crust (e.g. Ulmer \& Trommsdorff 1995; Escartm et al. 2001; Hilairet et al. 2007). However, because serpentinization affects only the upper $6 \mathrm{~km}$ of the mantle in the exhumation domain, its effect may be restricted to a relatively superficial level. We suggest that the difference in density and strength (Table 2, Fig. 3) between fertile mantle (mantle type 2) and inherited mantle (mantle type 1) or between fertile mantle and depleted mid-ocean ridge mantle (mantle type 3 ) may act as a stress guide for subduction initiation at greater depths $(6-30 \mathrm{~km})$.

The lack of significant subduction-related magmatism in the Pyrenees and the Alps was interpreted by, respectively, Boillot \& Capdevila (1977) and Sengör (1991) as a consequence of the narrow width of the closing ocean, which did not allow for significant decompression and/or flux melting. As a result, the mantle underlying orogens resulting from the closure of a hyperextended rift system or a narrow embryonic ocean is likely to be fertile. It is presumably hydrated and enriched by mobile components from subducting sediments, oceanic crust and dehydrating serpentinite (Anderson 2006). This fertile composition may add to the already fertile sub-lithospheric mantle preserved from the rift-related melt impregnation and provide fusible components for subsequent magmatic events (Fig. 2b; Chenin et al. 2017).

\section{Wide/mature oceans}

In contrast with the quasi-amagmatic closure of hyperextended rift systems, protracted subduction associated with the closure of a wide ocean is accompanied by intense magmatic activity, which forms volcanic arcs (Uyeda 1981). Subduction-related magma is generated by flux melting of the wet mantle wedge resulting from slab dehydration, and decompression melting of the hot asthenosphere, which rises to compensate the down-dragging of mantle wedge material by the slab (Iwamori 1998; Sisson \& Bronto 1998; Jagoutz et al. 2011). These melting processes deplete the source mantle wedge, as recognized by Martinez \& Taylor (2002) in the Lau and Mariana back-arc regions. This observation suggests that the incoming asthenosphere does not bring enough fertile material to equilibrate with the amount of fertile material that is taken out by arc magmatism and therefore orogens resulting from the closure of a wide ocean are potentially underlain by relatively depleted mantle (Chenin et al. 2017).

The extraction of mafic melts towards the surface also strongly affects the lithology and the thermal state of the hanging wall (Miyashiro 1961, 1967; Ernst et al. 1970; Gerya 2011). If the magmatic arc is intra-oceanic, it will be accreted in the orogenic wedge, whereas if the arc is built on the upper plate continental margin, it will affect the continental crust inboard of the future suture zone. In both cases, strong inheritance is expected in the orogenic domain.

\section{Hyperextended rift systems versus mature oceans and the Wilson cycle in the North Atlantic}

The Wilson cycle states that ocean basins open and close following roughly the same lines, which suggests a major structural control of inheritance. Among the inherited features supposed to facilitate extension and rifting, we can mention structural weaknesses or fabric (e.g. Ring 1994; Vauchez et al. 1997), compositional inheritance (e.g. Ryan \& Dewey 1997; Yamasaki et al. 2006; Petersen \& Schiffer 2016) and thermal inheritance (e.g. 


\section{LITHOSPHERIC MANTLE AND THE WILSON CYCLE}

Yamasaki \& Gernigon 2009; Vanderhaeghe 2012), which can exist in the crust as well as in the mantle. However, although complete Wilson cycles have been recognized in several places, occurring sometimes repeatedly along the same region (Thomas 2006), the theory is challenged in other regions (Krabbendam \& Barr 2000). In particular, in Western Europe, most of the Variscan sutures were not reactivated during the Mesozoic extensional phases, either by the North Atlantic rift, or by the Alpine
Tethys rift system (Frizon de Lamotte et al. 2011). This implies that either orogenic inheritance and/or post-orogenic processes vary among orogens.

The work by Chenin et al. (2015) and references cited therein highlighted major differences in the behaviour of the North Atlantic rift system, depending on whether it affects the Caledonian or Variscan orogenic lithosphere. In the northern North Atlantic, the rift parallels the Caledonian suture, rifting is protracted and polyphase and break-up is accompanied

\section{The classical Wilson cycle of Scandinavian Caledonides}

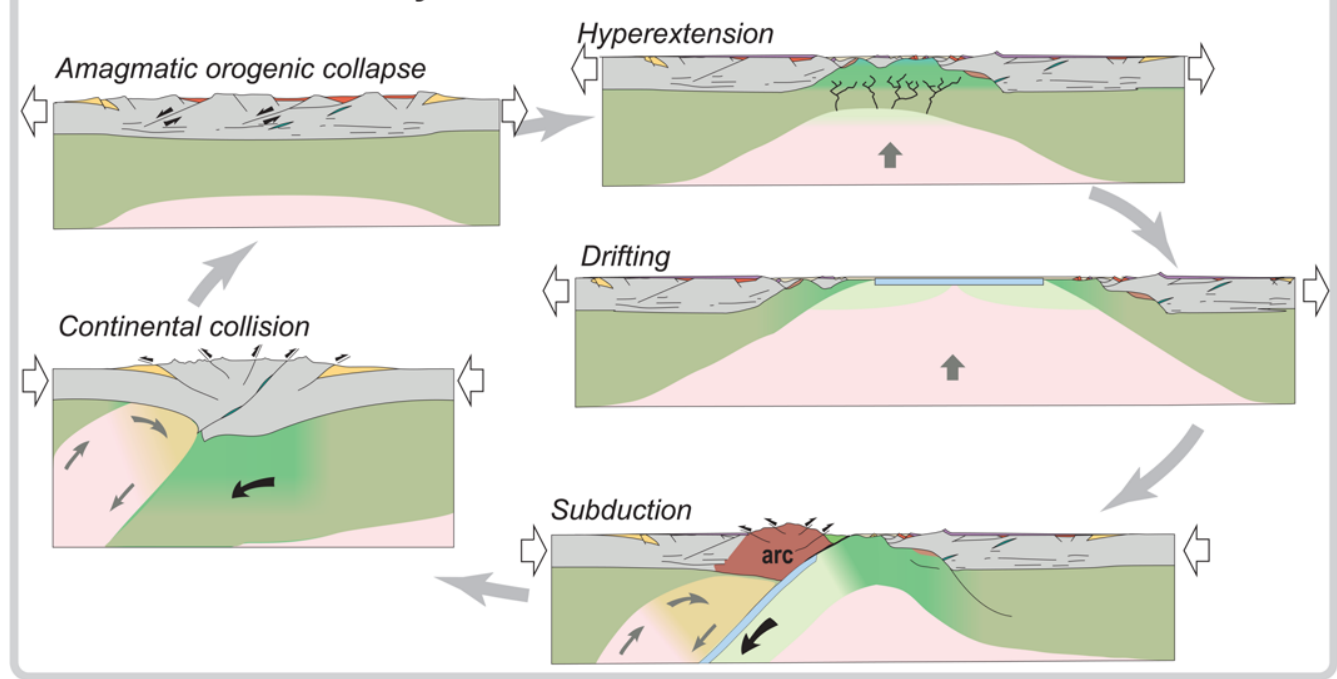

The incomplete Wilson cycle of the Variscides of Western Europe

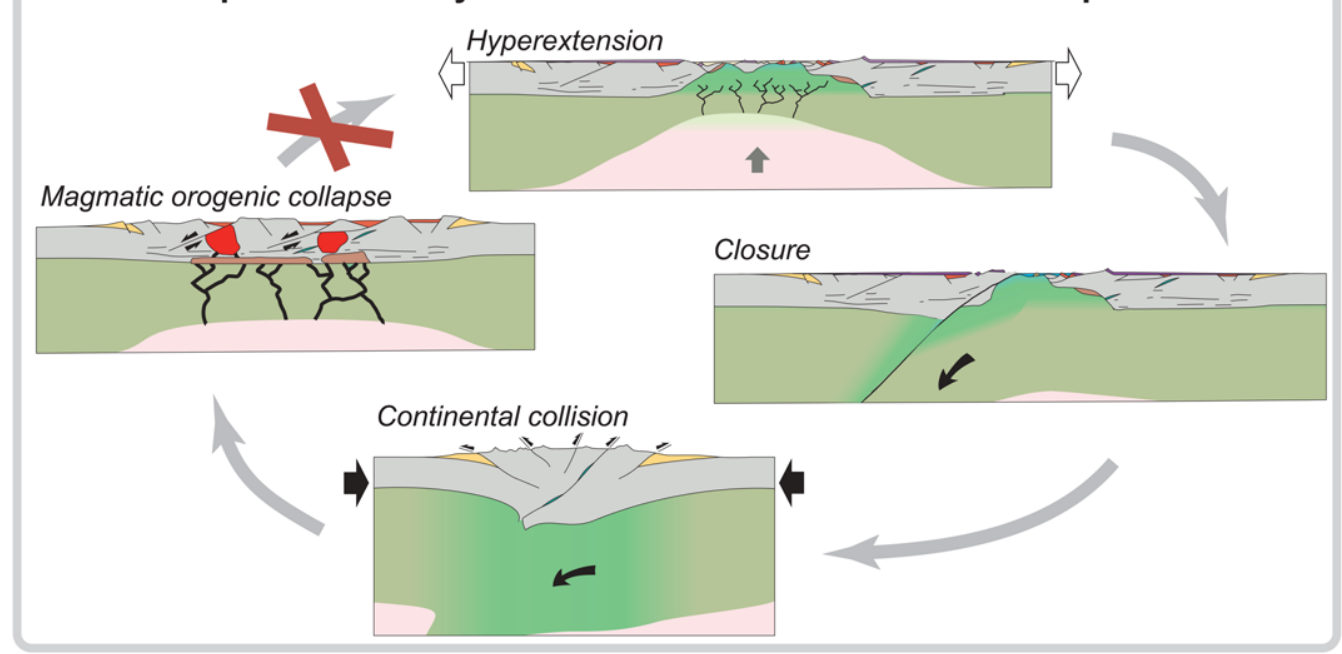

Fig. 4. Illustration of the two end-members proposed for the Wilson cycle in the North Atlantic. See Figure 2 for colour legend. 


\section{P. CHENIN ET AL}

by intense magmatic activity. By contrast, in the southern part of the North Atlantic, the rift circumvents the Variscan orogenic domain in Western Europe, the duration of rifting is much shorter than in the north and the break-up is magma-poor. They also noted that the orogenic collapse of the Scandinavian Caledonides was largely devoid of magma (Meissner 1999; Fossen et al. 2014), whereas the collapse of the Variscides was followed by intense magmatic activity (Costa \& Rey 1995; Schaltegger 1997; Petri 2014).

One major difference between the Scandinavian Caledonides and the Variscides of Western Europe is the number and size of ocean basins involved. The Scandinavian Caledonides resulted from the closure of the wide Iapetus Ocean between the two large Laurentian and Baltic cratonic shields, with only the limited accretion of magmatic arcs or terranes between Norway and Greenland (Roberts 2003; van Staal et al. 2012). By contrast, the Variscides of Western Europe resulted from the closure of a series of narrow oceans $(<500-1000 \mathrm{~km}$; McKerrow et al. 2000), in addition to the closure of the wide Rheic Ocean (Franke 2006; Kroner \& Romer 2013).

As highlighted in the previous sections, major differences in the characteristics of orogens can be expected, depending on whether they arise from the closure of a narrow hyperextended rift system or a wide and mature ocean. In particular, we focused this study on the role of the lithospheric mantle because it is often regarded as the strongest lithospheric layer and thus would largely control most tectonic events (e.g. Burov \& Watts 2006).

During a Wilson cycle, the mantle lithosphere may be modified by three different processes: (1) thermal processes, which may affect any part of the lithosphere, but with transient effects; (2) mantle depletion or enrichment due to the interactions of mantle rocks with melt - these compositional modifications may arise across the entire mantle lithosphere; and (3) serpentinization due to the hydration of mantle rocks, which is limited to shallow depths (with the exception of supra-detachment systems). These processes affect both the rheology and the melting potential of the mantle. For instance, the relatively fertile mantle presumed to underlie orogens resulting from the closure of narrow hyperextended rift systems may explain the magma-rich collapse of the Variscides of Western Europe. By contrast, the magma-poor collapse of the Scandinavian Caledonides could be explained by the depleted mantle that may underlie orogens formed after longlasting subduction and arc magmatism systems.

The magmatic budget of orogenic collapse may have a strong influence on the localization of future extension. Although Caledonian orogenic and postorogenic structures were largely reactivated during the rifting of the northern North Atlantic between
Norway and Greenland, illustrating the classic Wilson cycle, possible thermally equilibrated mafic underplating of the crust in the Variscan domain would have formed a strong core, which the subsequent Alpine Tethys and southern North Atlantic rifts circumvented.

Thus we propose two end-members for the Wilson cycle in the North Atlantic, depending on the maturity of the extensional system involved (Fig. 4). The classic Wilson cycle applies to the Scandinavian Caledonides. It involves: (1) the formation of a wide ocean; (2) protracted subduction of the oceanic domain forming magmatic arcs and depleting the mantle wedge beneath the orogen; (3) magma-poor orogenic collapse preserving both orogenic and post-orogenic structures; and (4) rifting within the former orogenic area when renewed extension takes place.

An incomplete Wilson cycle applies to the Variscides of Western Europe. It is characterized by: (1) the formation of a series of narrow oceans or hyperextended rift systems; (2) their closure, which is essentially mechanical and largely devoid of magmatic activity; (3) magma-rich orogenic collapse causing widespread underplating of the continental crust; (4) a long relaxation time leading to strengthening of the orogenic area; and (5) rifting outside the orogenic area during subsequent extension.

\section{Conclusions}

During the reversal of an extensional system and ultimate collision, the size and maturity of the basin/ ocean involved presumably have a major control on the orogenic and post-orogenic evolution. In particular, the fertilization processes of the lithospheric mantle during hyperextension, together with the lack of depletion caused by subduction-related magmatism during the closure of a narrow/immature ocean, allow for a relatively fertile mantle composition beneath the orogen. By contrast, the underlying mantle is proposed to be relatively depleted beneath orogens resulting from the closure of wide/mature oceans, both due to the depleted composition of the slab and the arc-related partial melting of the mantle wedge. Because the composition of the mantle controls both its rheology and its ability to melt, it probably influences both the localization and magmatic budget of subsequent tectonic events. This may help to explain the different behaviour of the North Atlantic rift depending on whether it affected the orogenic lithosphere of the Scandinavian Caledonides or the Variscides of Western Europe.

Despite its potential first-order control, the lithospheric mantle remains very poorly known and therefore further studies on the characteristics and evolution of the subcontinental mantle in various 


\section{LITHOSPHERIC MANTLE AND THE WILSON CYCLE}

tectonic settings, from outcrop to regional scales, are desperately required.

Acknowledgements We acknowledge careful reviews and helpful comments by Erik Lundin and an anonymous reviewer.

Funding This research was supported by ExxonMobil in the framework of the project CEIBA.

\section{References}

Afilhado, A., Matias, L., Shiobara, H., Hirn, A., MendesVictor, L. \& Shimamura, H. 2008. From unthinned continent to ocean: the deep structure of the West Iberia passive continental margin at $38^{\circ} \mathrm{N}$. Tectonophysics, 458, 9-50.

Andersen, T.B. 1998. Extensional tectonics in the Caledonides of southern Norway: an overview. Tectonophysics, 285, 333-351.

Anderson, D.L. 2006. Speculations on the nature and cause of mantle heterogeneity. Tectonophysics, 416, 7-22.

Artemieva, I.M., Thybo, H. \& Kaban, K.K. 2006. Deep Europe today: geophysical synthesis of the upper mantle structure and lithospheric processes over $3.5 \mathrm{Ga}$. In: GeE, D.G. \& Stephenson, R.A. (eds) European Lithosphere Dynamics. Geological Society London Memoirs, 32, 11-41, https://doi.org/10.1144/GSL.MEM. 2006.032.01.02

BaKer, J., Chazot, G., Menzies, M. \& Thirlwall, M. 1998. Metasomatism of the shallow mantle beneath Yemen by the Afar plume - implications for mantle plumes, flood volcanism, and intraplate volcanism. Geology, 26, 131 .

Beaumont, C., Fullsack, P. \& Hamilton, J. 1994. Styles of crustal deformation in compressional orogens caused by subduction of the underlying lithosphere. Tectonophysics, 232, 119-132.

Beltrando, M., Manatschal, G., Mohn, G., Dal Piaz, G.V., Vitale Brovarone, A. \& Masini, E. 2014. Recognizing remnants of magma-poor rifted margins in high-pressure orogenic belts: the Alpine case study. Earth-Science Reviews, 131, 88-115.

Boillot, G. \& CAPdeVILA, R. 1977. The Pyrenees: subduction and collision? Earth and Planetary Science Letters, 35, 151-160.

Bois, C., Pinet, B. \& Roure, F. 1989. Dating lower crustal features in France and adjacent areas from deep seismic profiles. In: Mereu, R.F., Mueller, F. et al. (eds) Properties and Processes of Earth's Lower Crust. American Geophysical Union, Geophysical Monographs, 51, 17-31.

Bown, J.W. \& White, R.S. 1994. Variation with spreading rate of oceanic crustal thickness and geochemistry. Earth and Planetary Science Letters, 121, 435-449.

Brune, S., Heine, C., Pérez-Gussinyé, M. \& Sobolev, S.V. 2014. Rift migration explains continental margin asymmetry and crustal hyper-extension. Nature Communications, 5, 4014.
Burov, E.B. \& WatTs, A.B. 2006. The long-term strength of continental lithosphere: - 'jelly sandwich' or 'creme brûlée'? GSA Today, 16, 4-10.

Cammarano, F., Goes, S., Vacher, P. \& Giardini, D. 2003. Inferring upper-mantle temperatures from seismic velocities. Physics of the Earth and Planetary Interiors, 138, 197-222.

Chen, W.P. \& Molnar, P. 1983. Focal depths of intracontinental and intraplate earthquakes and their implications for the thermal and mechanical properties of the lithosphere. Journal of Geophysical Research, 88, 4183-4214.

Chenin, P., Manatschal, G., Lavier, L.L. \& Erratt, D. 2015. Assessing the impact of orogenic inheritance on the architecture, timing and magmatic budget of the North Atlantic rift system: a mapping approach. Journal of the Geological Society, 172, 711-720, https:// doi.org/10.1144/jgs2014-139

Chenin, P., Manatschal, G., Picazo, S., Müntener, O., Karner, G.D., Johnson, C. \& Ulrich, M. 2017. Influence of the architecture of magma-poor hyperextended rifted margins on orogens produced by the closure of narrow v. wide oceans. Geosphere, 13, 1-18.

Christensen, N.I. 1970. Composition and evolution of the oceanic crust. Marine Geology, 8, 139-154.

Costa, S. \& Rey, P. 1995. Lower crustal rejuvenation and growth during post-thickening collapse: insights from a crustal cross section through a Variscan metamorphic core complex. Geology, 23, 905-908.

Dewey, J.F. 1988. Extensional collapse of orogens. Tectonics, 7, 1123-1139.

Dewey, J.F. \& BurKe, K. 1974. Hot spots and collisional break-up: implications for collisional orogeny. Geology, 2, 57-60.

Dick, H.J.B., Lin, J. \& Schouten, H. 2003. An ultraslowspreading class of ocean ridge. Nature, 426, 405-412.

DorÉ, T. \& Lundin, E. 2015. Hyperextended continental margins - knowns and unknowns. Geology, 43, 95-96.

ERnst, W.G., Seki, Y., OnUKi, H. \& Gilbert, M.C. 1970. Comparative Study of Low-Grade Metamorphism in the California Coast Ranges and the Outer Metamorphic Belt of Japan. Geological Society of America Memoirs, 124.

Escartm, J., Hirth, G. \& Evans, B. 2001. Strength of slightly serpentinized peridotites: implications for the tectonics of oceanic lithosphere. Geology, 29, 1023-1026.

Fossen, H., Gabrielsen, R.H., Faleide, J.I. \& Hurich, C.A. 2014. Crustal stretching in the Scandinavian Caledonides as revealed by deep seismic data. Geology, $\mathbf{4 2}$, 791-794.

FRANKE, W. 2006. The Variscan orogen in Central Europe: construction and collapse. In: GEE, D.G. \& STEPHENSON, R.A. (eds) European Lithosphere Dynamics. Geological Society London Memoirs, 32, 333-343, https:// doi.org/10.1144/GSL.MEM.2006.032.01.20

Frizon de Lamotte, D., Raulin, C., Mouchot, N., WrobelDaveau, J.-C., Blanpied, C. \& Rin- GenBaCh, J.-C. 2011. The southernmost margin of the Tethys realm during the Mesozoic and Cenozoic: initial geometry and timing of the inversion processes. Tectonics, 30, 1-22.

Früh-Green, G.L., Connolly, J.A., Plas, A., Kelley, D.S \& GRoBÉTY, B. 2004. Serpentinization of oceanic peridotites: implications for geochemical cycles and biological activity. In: Wilcock, W.S., DeLong, E.F., Kelley, D.S., 


\section{P. CHENIN ET AL.}

Baross, J.A. \& Craig CARY, S. (eds) The Subseafloor Biosphere at Mid-Ocean Ridges. American Geophysical Union, Geophysical Monographs, 144, 119-136.

Funck, T. 2003. Crustal structure of the ocean-continent transition at Flemish Cap: seismic refraction results. Journal of Geophysical Research, 108, 1-20.

Gale, A., Dalton, C.A., Langmuir, C.H., Su, Y. \& SchilLING, J.G. 2013. The mean composition of ocean ridge basalts. Geochemistry, Geophysics, Geosystems, 14, 489-518.

Gerya, T. 2011. Future directions in subduction modeling. Journal of Geodynamics, 52, 344-378.

Goes, S., Govers, R. \& VAcher, P. 2000. Shallow mantle temperatures under Europe from $\mathrm{P}$ and $\mathrm{S}$ wave tomography. Journal of Geophysical Research: Solid Earth, 105, 11153-11169.

Goetze, C. \& Poirier, J. 1978. The mechanisms of creep in olivine [and discussion]. Philosophical Transactions of the Royal Society of London A: Mathematical, Physical and Engineering Sciences, 288, 99-119.

Goodwin, E.B. \& McCARThy, J. 1990. Composition of the lower crust in west central Arizona from threecomponent seismic data. Journal of Geophysical Research, 95, 20097.

Gueydan, F., Morency, C. \& Brun, J.P. 2008. Continental rifting as a function of lithosphere mantle strength. Tectonophysics, 460, 83-93.

Hacker, B.R., Abers, G.A. \& Peacock, S.M. 2003. Subduction factory 1 . Theoretical mineralogy, densities, seismic wave speeds, and $\mathrm{H}_{2} \mathrm{O}$ contents. Journal of Geophysical Research, 108, 2029.

Hess, H. 1955. Serpentines, orogeny, and epeirogeny. In: Poldervaart, A. (ed.) Crust of the Earth: a Symposium. Geological Society of America Special Papers, 62, 391-408.

Hier-Majumder, S., Mei, S. \& Kohlstedt, D.L. 2005. Water weakening of clinopyroxene in diffusion creep. Journal of Geophysical Research, 110, B07406.

Hilairet, N., Reynard, B., Wang, Y., Daniel, I., Merkel, S., Nishiyama, N. \& Petitgirard, S. 2007. Highpressure creep of serpentine, interseismic deformation, and initiation of subduction. Science, $\mathbf{3 1 8}$ 1910-1913.

Huismans, R. \& Beaumont, C. 2011. Depth-dependent extension, two-stage breakup and cratonic underplating at rifted margins. Nature, 473, 74-78.

Huismans, R.S., Podladchikov, Y.Y. \& Cloetingh, S.A.P.L. 2001. Transition from passive to active rifting: relative importance of asthenospheric doming and passive extension of the lithosphere. Journal of Geophysical Research, 106, 11271-11291.

IwAmORI, H. 1998. Transportation of $\mathrm{H}_{2} \mathrm{O}$ and melting in subduction zones. Earth and Planetary Science Letters, 160, 65-80.

JACKSON, J. 2002. Faulting, flow, and the strength of the continental lithosphere. International Geology Review, 44, 39-61.

Jagoutz, O., Müntener, O., Schmidt, M.W. \& Burg, J.-P. 2011. The roles of flux- and decompression melting and their respective fractionation lines for continental crust formation: evidence from the Kohistan arc. Earth and Planetary Science Letters, 303, 25-36.

Jammes, S. \& Huismans, R.S. 2012. Structural styles of mountain building: controls of lithospheric rheologic stratification and extensional inheritance. Journal of Geophysical Research: Solid Earth, 117, B10403.

JAMMES, S. \& LAVIER, L.L. 2016. The effect of bimineralic composition on extensional processes at lithospheric scale. Geochemistry, Geophysics, Geosystems, 17, 3375-3392.

JAMMES, S., LAVIER, L.L. \& REBER, J.E. 2015. Localization and derealization of deformation in a bimineralic material. Journal of Geophysical Research, 120, 3649-3663.

JAUPART, C. \& MARESChAL, J.C. 2007. Heat flow and thermal structure of the lithosphere. Treatise on Geophysics, 6, 217-251.

Kohlstedt, D.L., Evans, B. \& Mackwell, S.J. 1995. Strength of the lithosphere: constraints imposed by laboratory experiments. Journal of Geophysical Research: Solid Earth, 100, 17587-17602.

Krabbendam, M. 2001. When the Wilson cycle breaks down: how orogens can produce strong lithosphere and inhibit their future reworking. In: Miller, J.A., Holdsworth, R.E., Buick, I.S. \& Hand, M. (eds). Continental Reactivation and Reworking. Geological Society, London, Special Publications, 184, 57-75, https:// doi.org/10.1144/GSL.SP.2001.184.01.04

KrabbendaM, M. \& BarR, T.D. 2000. Proterozoic orogens and the break-up of Gondwana: why did some orogens not rift? Journal of African Earth Sciences, 31, 35-49.

Kroner, U. \& Romer, R. 2013. Two plates - many subduction zones: the Variscan orogeny reconsidered. Gondwana Research, 24, 298-329.

Lagabrielle, Y. \& Bodinier, J.L. 2008. Submarine reworking of exhumed subcontinental mantle rocks: field evidence from the Lherz peridotites, French Pyrenees. Terra Nova, 20, 11-21.

Latin, D. \& White, N. 1990. Generating melt during lithospheric extension: pure shear v. simple shear. Geology, 18, 327-331.

Lau, K.W.H., Louden, K.E., Funck, T., Tucholke, B.E., Holbrook, W.S., Hopper, J.R. \& Christian Larsen, H. 2006. Crustal structure across the Grand BanksNewfoundland Basin continental margin - I. Results from a seismic refraction profile. Geophysical Journal International, 167, 127-156.

Lundin, E.R. \& DoRÉ, A.G. 2011. Hyperextension, serpentinization, and weakening: a new paradigm for rifted margin compressional deformation. Geology, 39, 347-350.

Maggi, A., Jackson, J.A., Priestley, K. \& Baker, C. 2000. A re-assessment of focal depth distributions in southern Iran, the Tien Shan and northern India: do earthquakes really occur in the continental mantle? Geophysical Journal International, 143, 629-661.

Manatschal, G. 1999. Fluid- and reaction-assisted lowangle normal faulting: evidence from rift-related brittle fault rocks in the Alps (Err Nappe, eastern Switzerland). Journal of Structural Geology, 21, 777-793.

Manatschal, G. 2004. New models for evolution of magma-poor rifted margins based on a review of data and concepts from West Iberia and the Alps. International Journal of Earth Sciences, 93, 432-466.

Manatschal, G., Lavier, L. \& Chenin, P. 2015. The role of inheritance in structuring hyperextended rift systems: some considerations based on observations and numerical modeling. Gondwana Research, 27, $140-164$. 


\section{LITHOSPHERIC MANTLE AND THE WILSON CYCLE}

Martinez, F. \& TAYloR, B. 2002. Mantle wedge control on back-arc crustal accretion. Nature, 416, 417-420.

McCarthy, A. \& Müntener, O. 2015. Ancient depletion and mantle heterogeneity: revisiting the PermianJurassic paradox of Alpine peridotites. Geology, 43, 255-258.

McKerrow, W.S., Mac Niocaill, C., Ahlberg, P.E., Clayton, G., Cleal, C.J. \& Eagar, R.M.C. 2000. The Late Palaeozoic relations between Gondwana and Laurussia. In: Franke, W., HaAk, V., Oncken, O. \& TAnner, D. (eds). Orogenic Processes: Quantification and Modelling in the Variscan Belt. Geological Society, London, Special Publications, 179, 9-20, https://doi.org/10. 1144/GSL.SP.2000.179.01.03

Meissner, R. 1999. Terrane accumulation and collapse in central Europe: seismic and rheological constraints Tectonophysics, 305, 93-107.

Meyer, R., van WiJk, J. \& Gernigon, L. 2007. The North Atlantic Igneous Province: a review of models for its formation. In: Foulger, G.R. \& Jurdy, D.M. (eds) Plates, Plumes and Planetary Processes. Geological Society of America, Special Papers, 430, 525-552.

MiYAShiRo, A. 1961. Evolution of metamorphic belts. Journal of Petrology, 2, 277-311.

MiYASHIRO, A. 1967. Orogeny, regional metamorphism, and magmatism in the Japanese Islands. Meddelelser fra Dansk Geologisk Forening, 17, 390-446.

Mohn, G., Manatschal, G., Beltrando, M. \& Haupert, I. 2014. The role of rift-inherited hyper-extension in Alpine-type orogens. Terra Nova, 26, 347-353.

Müntener, O., Pettke, T., Desmurs, L., Meier, M. \& SCHALTEGger, U. 2004. Refertilization of mantle peridotite in embryonic ocean basins: trace element and $\mathrm{Nd}$ isotopic evidence and implications for crust-mantle relationships. Earth and Planetary Science Letters, 221, 293-308.

Müntener, O., Manatschal, G., Desmurs, L. \& PettKe, T. 2010. Plagioclase peridotites in ocean-continent transitions: refertilized mantle domains generated by melt stagnation in the shallow mantle lithosphere. Journal of Petrology, 51, 255-294.

MutTer, J.C. \& ZEHNDER, C.M. 1988. Deep crustal structure and magmatic processes: the inception of seafloor spreading in the Norwegian-Greenland Sea. MoRTON, A.C. \& PARson, L.M. (eds) Early Tertiary Volcanism and the Opening of the NE Atlantic. Geological Society, London, Special Publications, 39, 35-48, https://doi. org/10.1144/GSL.SP.1988.039.01.05

O'Reilly, B., Hauser, F., Ravaut, C., Shannon, P. \& Readman, P. 2006. Crustal thinning, mantle exhumation and serpentinization in the Porcupine Basin, offshore Ireland: evidence from wide-angle seismic data. Journal of the Geological Society, 163, 775-787, https://doi.org/10.1144/0016-76492005-079

Perez-Gussinyé, M. \& Reston, T.J. 2001. Rheological evolution during extension at non-volcanic rifted margins: onset of serpentinization and development of detachments leading to continental breakup. Journal of Geophysical Research, 106, 3961-3975.

Peron-Pinvidic, G., Manatschal, G., Dean, S.M. \& MinShull, T.A. 2008. Compressional structures on the West Iberia rifted margin: controls on their distribution. In: Johnson, H., Doré, T.G., GatlifF, R.W.,
Holdsworth, R.W., Lundin, E.R. \& Ritchie, J.D. (eds) The Nature and Origin of Compression in Passive Margins. Geological Society, London, Special Publications, 306, 169-183, https://doi.org/10.1144/SP306.8

Peron-Pinvidic, G., Manatschal, G. \& Osmundsen, P.T. 2013. Structural comparison of archetypal Atlantic rifted margins: a review of observations and concepts. Marine and Petroleum Geology, 43, 21-47.

Petersen, K.D. \& Schiffer, C. 2016. Wilson cycle passive margins: control of orogenic inheritance on continental breakup. Gondwana Research, 39, 131-144.

Petri, B. 2014. Formation et exhumation des granulites permiennes. $\mathrm{PhD}$ thesis, Universite de Strasbourg.

Petri, B., Mohn, G., Štípská, P., Schulmann, K. \& ManaTSCHAL, G. 2016. The Sondalo gabbro contact aureole (Campo unit, Eastern Alps): implications for midcrustal mafic magma emplacement. Contributions to Mineralogy and Petrology, 171, 52.

Pfiffner, O.A., Ellis, S. \& Beaumont, C. 2000. Collision tectonics in the Swiss Alps: insight from geodynamic modeling. Tectonics, 19, 1065-1094.

Picazo, S., Cannat, M., Delacour, A., Escartín, J., Rouméjon, S. \& Silantyev, S. 2012. Deformation associated with the denudation of mantle-derived rocks at the Mid-Atlantic Ridge $13-15^{\circ} \mathrm{N}$ : the role of magmatic injections and hydrothermal alteration. Geochemistry, Geophysics, Geosystems, 13, Q04G09.

Picazo, S., Müntener, O., Manatschal, G., Bauville, A., Karner, G.D. \& Johnson, C. 2016. Mapping the nature of mantle domains in Western and Central Europe based on clinopyroxene and spinel chemistry: evidence for mantle modification during an extensional cycle. Lithos, 266-267, 233-263.

Pinto, V.H.G., Manatschal, G., Karpoff, A.M. \& Viana, A. 2015. Tracing mantle-reacted fluids in magma-poor rifted margins: the example of Alpine Tethyan rifted margins. Geochemistry, Geophysics, Geosystems, 16 , 3271-3308.

Raleigh, C., Kirby, S., Carter, N. \& Lallemant, H. 1971. Slip and the clinoenstatite transformation as competing rate processes in enstatite. Journal of Geophysical Research, 76, 4011-4022.

REY, P. 1993. Seismic and tectono-metamorphic characters of the lower continental crust in Phanerozoic areas: a consequence of post-thickening extension. Tectonics, 12, 580-590.

Rey, P., Vanderhaeghe, O. \& Teyssier, C. 2001. Gravitational collapse of the continental crust: definition, regimes and modes. Tectonophysics, 342, 435-449.

RING, U. 1994. The influence of preexisting structure on the evolution of the Cenozoic Malawi rift (East African rift system). Tectonics, 13, 313-326.

Roberts, D. 2003. The Scandinavian Caledonides: event chronology, palaeogeographic settings and likely modern analogues. Tectonophysics, 365, 283-299.

Rosenbaum, G., Weinberg, R.F. \& Regenauer-Lieb, K. 2008. The geodynamics of lithospheric extension. Tectonophysics, 458, 1-8.

Ryan, P.D. \& Dewey, J.F. 1997. Continental eclogites and the Wilson cycle. Journal of the Geological Society, 154, 437-442, https://doi.org/10.1144/gsjgs.154.3. 0437

SAunders, A.D., Norry, M.J. \& TARNeY, J. 1988. Origin of MORB and chemically-depleted mantle reservoirs: 


\section{P. CHENIN ET AL.}

trace element constraints. Journal of Petrology, 1, 415-445.

SchaltegGer, U. 1997. Magma pulses in the Central Variscan Belt: episodic melt generation and emplacement during lithospheric thinning. Terra Nova, 9, 242-245.

Schutt, D.L. \& Lesher, C.E. 2006. Effects of melt depletion on the density and seismic velocity of garnet and spinel lherzolite. Journal of Geophysical Research, 111, B05401.

SENGÖR, A.M.C. 1991. Orogenic architecture as a guide to size of ocean lost in collisional mountain belts. Bulletin of the Technical University of Istanbul, 44, 43-74.

Shelton, G. \& Tullis, A. 1981. Experimental flow laws for crustal rocks. Transactions of the American Geophysical Union, 62, 396.

Simon, N.S. \& PodladChiKov, Y.Y. 2008. The effect of mantle composition on density in the extending lithosphere. Earth and Planetary Science Letters, 272, 148-157.

Sisson, T.W. \& Bronto, S. 1998. Evidence for pressurerelease melting beneath magmatic arcs from basalt at Galunggung, Indonesia. Nature, 391, 883-886.

Sobolev, S.V., Zeyen, H., Stoll, G., Werling, F., Altherr, R. \& Fuchs, K. 1996. Upper mantle temperatures from teleseismic tomography of French Massif Central including effects of composition, mineral reactions, anharmonicity, anelasticity and partial melt. Earth and Planetary Science Letters, 139, 147-163.

Sutra, E., Manatschal, G., Mohn, G. \& Unternehr, P. 2013. Quantification and restoration of extensional deformation along the Western Iberia and Newfoundland rifted margins. Geochemistry, Geophysics, Geosystems, 14, 2575-2597.

Thomas, W.A. 2006. Tectonic inheritance at a continental margin. GSA Today, 16, 4-11.

Timmerman, M.J. 2004. Timing, geodynamic setting and character of Permo-Carboniferous magmatism in the foreland of the Variscan Orogen, NW Europe. In: WILSON, M., Neumann, E.-R., Davies, G.R., Timmerman, M.J., Heeremans, M. \& Larsen, B.T. (eds) Permo-Carboniferous Magmatism and Rifting in Europe. Geological Society, London, Special Publications, 223, 41-74, https://doi. org/10.1144/GSL.SP.2004.223.01.03

Tugend, J., Manatschal, G., Kusznir, N.J., Masini, E., Moнn, G. \& Thinon, I. 2014. Formation and deformation of hyperextended rift systems: insights from rift domain mapping in the Bay of Biscay-Pyrenees. Tectonics, 33, 1239-1276.
Tugend, J., Manatschal, G. \& KuszniR, N. 2015. Spatial and temporal evolution of hyperextended rift systems: implication for the nature, kinematics and timing of the Iberian-European plate boundary. Geology, 43, 15-18.

Ulmer, P. \& TrommsdorfF, V. 1995. Serpentine stability to mantle depths and subduction-related magmatism. Science, 268, 858.

UyedA, S. 1981. Subduction zones and back arc basins - a review. Geologische Rundschau, 70, 552-569.

van Staal, C.R., Barr, S.M. \& Murphy, J.B. 2012. Provenance and tectonic evolution of Ganderia: constraints on the evolution of the Iapetus and Rheic oceans. Geology, 40, 987-990.

VANDERHAEGHE, O. 2009. Migmatites, granites and orogeny: flow modes of partially-molten rocks and magmas associated with melt/solid segregation in orogenic belts. Tectonophysics, 477, 119-134.

VANDERHAEGHE, O. 2012. The thermal-mechanical evolution of crustal orogenic belts at convergent plate boundaries: a reappraisal of the orogenic cycle. Journal of Geodynamics, 56-57, 124-145.

Vanderhaeghe, O., Burg, J.-P. \& Teyssier, C. 1999. Exhumation of migmatites in two collapsed orogens: Canadian Cordillera and French Variscides. In: RING, U., Brandon, M.T., Lister, G.S. \& Willett, S.D. (eds) Exhumation Processes: Normal Faulting, Ductile Flow and Erosion. Geological Society, London, Special Publications, 154, 181-204, https://doi.org/10. 1144/GSL.SP.1999.154.01.08

Vauchez, A., Barruol, G. \& Tommasi, A. 1997. Why do continents break-up parallel to ancient orogenic belts? Terra Nova, 9, 62-66.

WiLson, J.T. 1966. Did the Atlantic close and then re-open? Nature, 211, 676-681.

Withuack, M.O., Baum, M.S. \& Schlische, R.W. 2010. Influence of preexisting fault fabric on inversion-related deformation: a case study of the inverted Fundy rift basin, southeastern Canada. Tectonics, 29, 1-22.

YAMASAKI, T. \& GERnigon, L. 2009. Styles of lithospherie extension controlled by underplated mafic bodies. Tectonophysics, 468, 169-184.

Yamasaki, T., O'Reilly, B. \& Readman, P. 2006. A rheological weak zone intensified by post-rift thermal relaxation as a possible origin of simple shear deformation associated with reactivation of rifting. Earth and Planetary Science Letters, 248, 119-131. 